\title{
Job Stress of Industrial Employees with Reference to Gender and
}

\section{Age Factor}

\author{
Tarlika L Zalawadia ${ }^{1 *}$
}

\section{ABSTRACT}

The present investigation is to find out the differences in job stress of male and female employees of industrial area in Rajkot city. The sample consisted of 200 employees out of which100 were male and 100 were female. For this purpose of investigation Occupational Stress Index (OSI) constructed and standardize by Dr. A. K. Srivastava and A. P. Singh used. The data obtained were analyzed through ' $\mathrm{t}$ ' test to know the mean difference between the two groups. Result is that the job stress of male and female employees is of the same levels. As well as the job stress of less than and more than 30 year employees is of the same levels. And no any significant difference between less than and more than 30 year male employees of job stress

Keywords: Job stress, Male, Female, Age, employee.

Stress isn't always bad. A little bit of stress can help you stay focused, energetic, and able to meet new challenges in the workplace. It's what keeps you on your toes during a presentation or alert to prevent accidents or costly mistakes. But in today's hectic world, the workplace too often seems like an emotional roller coaster. Long hours, tight deadlines, and ever-increasing demands can leave you feeling worried, drained, and overwhelmed. And when stress exceeds your ability to cope, it stops being helpful and starts causing damage to your mind and body-as well as to your job satisfaction. If stress on the job is interfering with your work performance, health, or personal life, it's time to take action. No matter what you do for a living, or how stressful your job is, there are plenty of things you can do to reduce your overall stress levels and regain a sense of control at work.

Job stress comes in different forms and affects your mind and body in different ways. Small things can make you feel stressed, such as a copy machine that never seems to work when you need it or phones that won't quit ringing. Major stress comes from having too much or not

\footnotetext{
${ }^{1}$ Associate Professor, Smt. R. R. Patel Mahila Arts \& Commerce College, Rajkot, Gujarat, India *Responding Author

(C) 2016 I Tarlika L Zalawadia; licensee IJIP. This is an Open Access Research distributed under the terms of the Creative Commons Attribution License (http://creativecommons.org/licenses/by/2.0), which permits unrestricted use, distribution, and reproduction in any Medium, provided the original work is properly cited.
} 


\section{Job Stress of Industrial Employees with Reference to Gender and Age Factor}

enough work or doing work that doesn't satisfy you. Conflicts with your boss, coworkers, or customers are other major causes of stress.

Dopkeen, Jonathan, Dubois, Renee (2014). Stress-related disorders encompass a broad array of conditions, including psychological disorders (e.g., depression, anxiety, post-traumatic stress disorder) and other types of emotional strain (e.g., dissatisfaction, fatigue, tension, etc.), maladaptive behaviors (e.g., aggression, substance abuse), and cognitive impairment (e.g., concentration and memory problems). In turn, these conditions may lead to poor work performance, higher absenteeism, less work productivity or even injury. "If untreated, consistently high stress can become a chronic condition, which can exacerbate existing mental health conditions and chronic physical conditions (diabetes, hypertension, weak immune system). These conditions not only diminish the well-being of workers and increase the employer's health benefits expenses; they contribute to increased injury incidence. Consistently high levels of stress increase the risk of occupational injury. A study of light/short haul truckers, a group that experiences high rates of injury and mental health issues, found that frequent stress increased the odds of occupational injury by $350 \%$.

Sunita, Urvashi Singh, Shalini Singh, Rajnee Sharma (2015) found that the negative relationship between organisational stress and OCBs. Results of regression analysis also exhibited the negative impact of stress on OCBs. The implications for the employees are discussed. job stress predicts OB negatively explaining $10 \%$ of variance. The sample for this investigation was obtained from the population of all the operators of call centre organisations located in Gurgaon as this considered a major hub of the call centre industry. The total sample of 250 call centre employees whose major task was to receive and answer the international calls of their customers. These employees were working under $24 \times 7$ conditions with different shifts. All belonged to an age group of 24-30 years, married and at least Graduates. Their minimum work experience was 4-5 years and it was in corporate sector only.

\section{Objective:}

- To study differences between male and female and less and more than 30 year age employees relation to their job stress.

\section{Hypotheses:}

1. There is no significant difference between male and female employees of job stress.

2. There is no significant difference between less than 30 year and more than 30 year employees of job stress.

3. There is no significant difference between less than 30 year and more than 30 year male employees of job stress.

4. There is no significant difference between less than 30 year and more than 30 year female employees of job stress. 


\section{METHOD}

\section{Sample:}

As a sample for the present study in Rajkot industrial area, 200 male and female employees were selected. 100 were taken from male and 100 were taken from female employees.

\section{Tool:}

Occupational Stress Index (OSI): This scale was constructed and standardize by Dr. A. K. Srivastava and A. P. Singh. The inventory consists of 46 items, each item is provided with five alternatives 'Strongly Agree’, 'more agree’, ‘agree’, 'disagree’, and ‘disagree’, Reliability of the inventory was found by test retest method, and it was found to be .93. The correlation between the scores on the occupational stress inventory and the measure of the job anxiety (Srivastava, 1974) was found to be $.59(\mathrm{~N}=400)$. The employee's scores on occupational stress inventory have been found to be positively correlated with their scores on the measure on mental health, standardized by Dr. O. N. Shrivastava.

\section{Procedure:}

The collection of data was spread over a period of 25 days. The researcher personally visited the selected industry and contacted male and female employees in Rajkot district. On the schedule date, the researcher met the male and female employees and made clear to them the purpose of administration. The researcher sought their co-operation. The instructions were explained by the researcher and the doubts were clarified. They were assured that their response will be used for research purpose only and will be kept confidential. They were suggested to give free, frank and honest responses without any hesitation. The scales were administered to the people. The scales were collected only after they were responded by the subject. After the completion of the administration, the investigator conveyed her gratitude and thanks to all subjects for their kind co-operation. The raw scores were statistically analyzed in terms of means; standard deviation and t-test were used to compare job stress level of the industrial employees in relation to their gender and age factor.

\section{RESULTS AND CONCLUSION}

The main objective of present study was to carry out the study of job stress level of industrial employees with reference to gender and age factor. In it statistical ' $t$ ' method was used.

Results discussion of present study is as under:

Table-1 job stress of male and female employees

\begin{tabular}{|lccccccl|}
\hline Group & $\mathbf{N}$ & Mean & SD & SE & SED & 't' & Sign. \\
\hline Male & 100 & 16.78 & 2.72 & 0.27 & & & \\
Female & 100 & 16.29 & 3.04 & 0.30 & & 1.20 & NS \\
\hline
\end{tabular}

Non-Significant $(0.05=1.98)$

(c) The International Journal of Indian Psychology, ISSN 2348-5396 (e)| ISSN: 2349-3429 (p) | 202 


\section{Job Stress of Industrial Employees with Reference to Gender and Age Factor}

Table no.-1 shows job stress of male employees and female employees. For the male employees mean is 16.78 and for female employees mean is 16.29, S.D. for male employees 2.72 and female employees 3.04. For both groups't' value is 1.20 and level of significance is not significant. Thus the null hypothesis, number 1 , which states "there is no significant difference between male and female employees of job stress”, was accepted. It means that the job stress of male and female employees is of the same levels.

Table-2 Job stress of less than and more than 30 year employees

\begin{tabular}{|lccccccl|}
\hline Group & N & Mean & SD & SE & SED & 't' & Sign. \\
\hline Less 30 Year & 122 & 16.43 & 2.97 & 0.27 & & & \\
More 30 year & 78 & 16.68 & 2.76 & 0.31 & & & \\
& & & & & & & \\
\hline
\end{tabular}

Non-Significant $(0.05=2.00)$

Table no.-2 shows job stress of less than and more than 30 year employees. For the less than 30 year employees mean is 16.43 and more than 30 year employees mean is 16.68, S.D. for less than 30 year employees 2.97 and more than 30 year employees 2.76. For both groups 't' value is 0.59 and level of significance is not significant. Thus the null hypothesis, number 2, which states "there is no significant difference between less than and more than 30 year employees of job stress" was accepted. It means that the job stress of less than and more than 30 year employees is of the same levels.

Table-3 Job stress of less than and more than 30 year male employees

\begin{tabular}{|lccccccc|}
\hline Group & N & Mean & SD & SE & SED & 't' & Sign. \\
\hline Less-30(male) & 56 & 16.86 & 2.75 & 0.37 & & & \\
More-30(male) & 44 & 16.66 & 2.70 & 0.41 & & & \\
& & & & & & & \\
\hline
\end{tabular}

Non-Significant $(0.05=2.00)$

Table no.-3 shows job stress of less than and more than 30 year male employees. For the less than 30 year male employees mean is 16.86 and more than 30 year male employees mean is 16.66, S.D. for less than 30 year male employees 2.75 and more than 30 year male employees 2.70. For both groups 't' value is 0.36 and level of significance is not significant. Thus the null hypothesis, number 3 , which states "there is no significant difference between less than and more than 30 year male employees of job stress” was accepted. It means that the job stress of less than and more than 30 year male employees is of the same levels. 
Job Stress of Industrial Employees with Reference to Gender and Age Factor

Table-4 Job stress of less than and more than 30 year female employees

\begin{tabular}{|llllclll|}
\hline Group & N & Mean & SD & SE & SED & 't' & Sign. \\
\hline Less-30(female) & 66 & 16.08 & 3.12 & 0.38 & & & \\
& & & & & 0.64 & 0.98 & NS \\
More-30(female) & 34 & 16.71 & 2.89 & 0.50 & & &
\end{tabular}

Non-Significant $(0.05=2.00)$

Table no.-4 shows job stress of less than and more than 30 year female employees. For the less than 30 year female employees mean is 16.08 and more than 30 year female employees mean is 16.71, S.D. for less than 30 year female employees 3.12 and more than 30 year female employees 2.89. For both groups ' $t$ ' value is 0.98 and level of significance is not significant. Thus the null hypothesis, number 4 , which states "there is no significant difference between less than and more than 30 year female employees of job stress" was accepted. It means that the job stress of less than and more than 30 year female employees is of the same levels.

\section{REFERENCES}

Beehr, T. (1998). An organizational psychology meta-model of occupational stress. In C. L. Cooper (Ed.). Theories of organizational stress. (pp. 6-27). Oxford, UK: Oxford University Press.

Colligan, Thomas W; Colligan MSW; Higgins M. (2006). "Workplace Stress - Etiology and Consequences" (PDF). Journal of Workplace Behavioral Health. 21 (2): 89-97. doi:10.1300/J490v21n02_07

Cooper, C.L. (Ed.)

Dopkeen, Jonathan, Dubois, Renee (2014). "Stress in the Workplace: A Policy Synthesis on Its Dimensions and Prevalence" (PDF)

Goetzel, RZ, Anderson, DR, Whitmer, RW, Ozminkowski, RJ, Dunn, RL, Wasserman J [1998]. The relationship between modifiable health risks and health care expenditure: An analysis of the multi-employer HERO health risk and cost database. $J$ Occup Environ Med 40:843-854.

Hart, P.M. \& Cooper, C.L. (2001). Occupational Stress: Toward a More Integrated Framework. In N. Anderson, D.S. Ones, H.K. Sinangil, \& C. Viswesvaran (Eds), Handbook of Industrial, Work and Organizational Psychology (vol 2: Personnel Psychology). London: Sage.

Hart, P.M. (1999). "Predicting employee life satisfaction: a coherent model of personality, work and nonwork experiences, and domain satisfactions". Journal of Applied Psychology. 84 (4): 564-584. doi:10.1037/0021-9010.84.4.564.

HELPGUIDE.ORG. Stress in the Workplace: Managing Job and Workplace Stress, Retrieved from https://www.helpguide.org/articles/stress/stress-in-the-workplace.htm 


\section{Job Stress of Industrial Employees with Reference to Gender and Age Factor}

Mark, G.M, and Smith, Andrew Paul. 2008. Stress models: a review and suggested new direction. Occupational Health Psychology, European Perspectives On Research, Education and Practice, vol. 3. Nottingham: Nottingham University Press, pp. 111-144.

Naghieh, Ali; Montgomery, Paul; Bonell, Christopher P; Thompson, Marc; Aber, J Lawrence; Naghieh, Ali (2015). "Organisational interventions for improving wellbeing and reducing work-related stress in teachers". The Cochrane Database of Systematic Reviews. 4: CD010306.

Sauter S, Hurrell J, Murphy L, Levi L [1997]. Psychosocial and organizational factors. In: Stellman J, ed. Encyclopaedia of Occupational Health and Safety. Vol. 1. Geneva, Switzerland: International Labour Office, pp. 34.1-34.77.

Srivastava, A.K. \& Singh, A.P. (1981) Manual of the Occupational stress Index, Department of Psychology, Banaras Hindu University, Varanasi

Sunita, Urvashi Singh, Shalini Singh, Rajnee Sharma (2015). Work Stress and Organisational Citizenship Behaviours (OCBs) in Call Centers Employees. International Journal of Indian Psychology. Vol. 3. Iss. 1

WebMD, Managing Job Stress-Overview. Retrieved from https://www.webmd.com/balance/stress-management/tc/managing-job-stress-topicoverview\#1

How to cite this article: Tarlika L Zalawadia (2016), Job Stress of Industrial Employees with Reference to Gender and Age Factor, International Journal of Indian Psychology, Volume 3, Issue 3, No. 11, DIP: 18.01.211/20160303, ISBN: 978-1-365-21307-6 